\title{
Changes in approximate composition, antioxidant activity and melatonin content of rapeseed during germination
}

\author{
Seok Joong Kim* \\ Department of Food and Nutrition, Seoul 02748, Korea
}

\section{발아기간에 따른 유채종자의 일반성분 조성, 항산화능 및 멜라토닌 함량의 변화}

\author{
김석중* \\ 동덕여자대학교 식품영양학과
}

\begin{abstract}
The changes of approximate composition, antioxidant activity and melatonin content in rapeseed were monitored during 10 days germination to choose the optimum sprouts with beneficial functionalities. The moisture content of seeds increased from $3.23 \%$ to $17.50 \%$ during 10 days germination period, while ash content was similar (4.03 4.91\%). The fat content was reduced from $38.18 \%$ to $22.65 \%$, however, protein content increased from $21.43 \%$ to $26.72 \%$. The carbohydrate content increased from $32.71 \%$ to $35.84 \%$ at 8 th day. The reducing sugar and fiber contents reached $10.47 \%$ and $15.12 \%$ at 6 th day from $4.04 \%$ and $12.82 \%$, respectively. Eighth day sprouts contained highest level of polyphenol (gallic acid equivalent, $19.2 \mathrm{~g} / \mathrm{kg}$ ). Germination increased antioxidant activities (trolox equivalent, $\mathrm{mmol} / \mathrm{kg}$ ) of seeds with slight difference depending on assay. That is, antioxidant activity was highest at 6th day in DPPH radical scavenging (55.9), 10th day both in ABTS radical scavenging (71.6) and Fe(III) reducing (125.3), and 4th day in peroxy radical scavenging (116.7) assay. Melatonin content of seeds $(0.85 \mu \mathrm{g} / \mathrm{kg})$ also increased and reached up to $14.93 \mathrm{\mu g} / \mathrm{kg}$ at 6 th day. In conclusion, germination more than 4 days raised antioxidant activity of seeds highly, and 6th day sprouts had additional benefit in terms of melatonin, reducing sugar and crude fiber contents.
\end{abstract}

Key words : rapeseed, germination, sprout, antioxidant, melatonin

\section{서 론}

세계적으로 주요한 유지자원 중 하나인 유채(Brassica napus L.)종자에는 35 45\%의 지방이 존재하며 다른 유지에 비해 포화지방산 함량은 낮고 단일불포화지방산과 다가불 포화지방산 함량이 높고 특히 오메가-6 지방산인 리놀레산 과 오메가-3 지방산인 a-리놀렌산의 비율이 2:1로 존재하여 건강에 좋은 조성을 가지고 있다 $(1,2)$. 탈지박도 단백질 함 량이 30 45\% 정도로 높아 가축사료로도 사용된다(3). 이외

*Corresponding author. E-mail : skim@dongduk.ac.kr Phone : 82-2-940-4466, Fax : 82-2-940-4610

Received 7 October 2016; Revised 19 October 2016; Accepted 19 October 2016.

Copyright (c) The Korean Society of Food Preservation. All rights reserved.
에도 유채종자에는 페놀화합물, 파이토스테롤, 토코페롤과 같은 다양한 생리활성 물질도 풍부하여 관상동맥 질환, 암, 당뇨병, 고혈압, 치매 등의 질환에 도움이 되며 4,5$)$ 다른 유지종자에 비해 극성 페놀화합물이 10 배 가량 풍부한데 주요 페놀화합물로는 sinapine, sinapoyl glucose, sinapic acid 등이 알려져 있다(6,7).

하지만 재래 유채종자에는 무기물 흡수를 방해하는 피트 산(phytic acid), 갑상선기능 저하를 유발하는 글루코시놀레 이트(glucosinolate)(8,9), 심장질환 유발물질인 에루스산 (erucic acid)(10)과 같은 영양저해인자들이 많아 식용유나 사료로 활용하는데 제약이 있었다. 이에 1979년 캐나다에 서는 품종개량을 통해 영양저해인자를 낮춘 유채종자를 얻어 이로부터 글루코시놀레이트와 에루스산의 함량을 각 각 $2 \%$ 와 $30 \mu \mathrm{mol} / \mathrm{g}$ 이하로 낮춘 유채유인 캐놀라(canola)유 를 개발하여 현재 식용유로서 이용하고 있다(11). 
한편, 식용소재로서 종자의 문제점을 개선하고 영양가나 생리활성을 증진시켜 건강 기능성 식품으로 이용하고자 종자를 발아시키기도 한다. 일반적으로 종자를 발아시키면 트립신저해제, 피트산, 펜토산, 탄닌 등과 같은 영양저해인 자들은 감소하는 반면, 탄수화물, 단백질, 지방 등은 가수분 해되어 소화성이 높아지며 비타민, 페놀화합물같은 생리활 성물질이 증가하여 건강에 유익한 점이 많은 것으로 알려져 있다(12). 유채종자의 발아로 얻은 싹에서도 글루코시놀레 이트(13), 에루스산(14), 피트산(15) 등은 감소하고, 토코페 롤(16), 비타민 $\mathrm{C}(17)$, 환원형 글루타치온(18) 등의 항산화 성분은 증가한다고 보고되어 있다.

최근에는 새로운 기능성 성분으로서 멜라토닌(melatonin, $\mathrm{N}$-acetyl-5-methoxytryptamine)도 유채종자의 발아 싹에서 확인되었다(19). 멜라토닌은 인체의 송과선에서 분비되는 호르몬으로 발견 초기에는 척추동물에서 계절 및 24시간 주기조절 호르몬으로 알려졌으나(20) 이 후 많은 연구를 통해 이 물질은 강한 항산화능을 가지며 면역조절, 항염증, 항암, 노화방지 등에 효과가 있다고 알려졌다(21). 그리고 이러한 효능들은 멜라토닌이 활성산소를 직접 소거할 수 있는 능력(22)뿐 아니라 세포 내 항산화효소 활성에 대해 간접적으로도 조절하는 능력(23)이 있어 in vivo 및 in vitro 모두에서 매우 효과적으로 작용하기 때문으로 알려져 있다 (21). 현재 멜라토닌은 동물 외에도 식물, 미생물, 그리고 이들 유래의 식품에서도 확인되었으며 $(24,25)$, 이들 소재를 섭취하면 멜라토닌이 체내에 흡수되어 생리적 역할을 할 수 있음이 확인되었다(26).

이처럼 유채종자를 발아시켜 싹으로 섭취하는 경우 다양 한 효능을 기대할 수 있지만, 싹의 섭취 시기의 결정은 이러 한 기능성보다 대부분 오염(27)이나 관능적인 측면(28)에 서 이루어지고 있다. 또한 주요 기능성인 항산화능을 분석 한 연구 결과들도 대부분 특정 기간 발아시킨 싹에 대한 것이거나 항산화 분석법의 특성을 고려하지 않은 경우가 많았다. 이에 본 연구에서는 유채종자의 발아동안 일반성 분의 변화, 다양한 항산화 분석법을 통한 항산화능 비교 및 멜라토닌 함량 변화를 분석함으로서 유채싹의 기능성을 최대로 이용할 수 있는 발아시기를 결정하고자 하였다.

\section{재료 및 방법}

\section{실험재료}

실험에 사용한 유채종자와 발아용기는 (주)아시아 종묘 (Seoul, Korea)에서 구입하였다. Folin-Ciocalteu's phenol 시 약, gallic acid, 1,1-diphenyl-2-picrylhydrazyl(DPPH·), 2,2'azinobis(3-ethylbenzo thiazoline-6-sulfonic acid(ABTS), ferric 2,4,6-tripyridyl-s-triazine(TPTZ), ferrous sulfate heptahydrate $\left(\mathrm{FeSO}_{4} \cdot 7 \mathrm{H}_{2} \mathrm{O}\right)$, ferric chloride hexahydrate $\left(\mathrm{FeCl}_{3} \cdot 6 \mathrm{H}_{2} \mathrm{O}\right)$, 2,2'-azobis(2-amidino propane) dihydrochloride(AAPH), 6hydroxy-2,5,7,8-tetramethylchroman-2-carboxylic acid (trolox) 는 Sigma-Aldrich 사(St. Louis, MO, USA)의 제품을, fluorescein은 Thermo Fisher Scientific 사(Waltham, MA, USA) 제품을 사용하였다. 멜라토닌 분석을 위한 ELISA 키트는 IBL International 사(Hamburg, Germany)의 제 품이 었으며 그 외 시약들은 분석 등급용을 구입하여 사용하였 다.

\section{종자 발아 및 시료분말 조제}

유채종자의 발아를 위해 먼저 $100 \mathrm{ppm}$ 차아염소산 나트 륨 $(\mathrm{NaOCl})$ 용액에 종자를 30 분간 침지하여 소독시킨 다음, 수돗물로 세척 후 상온의 멸균수에 6시간 침지시켰다. 이 후 종자를 발아용기에 파종하여 물을 매일 갈아주면서 $24 \pm 0.1^{\circ} \mathrm{C}$ 온도의 암소에서 10 일 동안 발아시켰다. 2 일 간격 으로 싹을 채취하고 30 개에 대한 길이를 측정하여 생육정 도를 확인하였으며, 종자와 각 발아시기별 싹은 동결건조 (FDU-2200, Eyela, Tokyo, Japan)한 후 액체질소에서 분쇄 하여 분말을 조제하였다.

\section{일반성분}

종자 및 발아싹의 수분, 조지방, 조단백질, 조회분, 탄수 화물의 분석은 $\mathrm{AOAC}$ 표준분석법에 준하여 $\mathrm{Kim}$ 의 방법 (29)에 따라 실시하였다. 즉, 건조시킨 분말시료에 대해 수 분은 $105^{\circ} \mathrm{C}$ 상압가열건조법, 조지방은 Soxhlet 추출법, 조단 백질은 Kjeldahl 법, 조회분은 $550^{\circ} \mathrm{C}$ 에서 직접 회화시켜 중 량법으로 정량하였으며 탄수화물은 총 중량에서 이들 성분 을 제한 값으로 산출하였다. 그리고 환원당은 Somogyi법, 조섬유는 변형 Henneberg-Stohmann법으로 정량하였다 (29).

\section{총 페놀함량}

총 페놀함량을 분석하기 위하여 분말시료에 메탄올을 첨가 $(1: 10, \mathrm{w} / \mathrm{v})$ 한 후 2 시간 동안 vortexing한 다음 $4{ }^{\circ} \mathrm{C}$, $10,000 \times \mathrm{g}$ 조건에서 10 분간 원심분리(5810R, Eppendorf, Hamburg, Germany)하였으며 이 때 얻어진 상등액을 시료 용액으로 사용하였으며 총 페놀함량은 Kim의 방법(29)에 따라 분석하였다. 이를 위해 시료용액 $50 \mu \mathrm{L}$ 에 증류수 1.95 $\mathrm{mL}$ 를 첨가한 후 $2 \mathrm{~N}$ Folin-Ciocalteu's phenol 시약 200 $\mu \mathrm{L}$ 를 가하여 상온에서 3 분간 반응시켰다. 여기에 $\mathrm{Na}_{2} \mathrm{CO}_{3}$ 포화용액 $400 \mu \mathrm{L}$ 과 증류수 $1.4 \mathrm{~mL}$ 를 순서대로 추가한 다음 상온 암소에서 1시간 반응시킨 후 $765 \mathrm{~nm}$ 에서의 흡광도 (Optizen Pop, Mecasys Co., Ltd., Daejeon, Korea)를 측정하 였다. 총 페놀함량은 gallic acid를 표준물질로 하여 얻어진 표준곡선을 이용하여 gallic acid 당량(equivalent)(g/kg)으로 나타내었다. 


\section{$\mathrm{DPPH}$ 라디칼 소거능}

시료의 DPPH 라디칼 소거능 분석은 $\mathrm{Kim}$ 의 방법(29)에 따라 실시하였다. 먼저, $100 \mathrm{mM} \mathrm{DPPH}$ 메탄올 용액을 조제 한 후 사용 전에 $517 \mathrm{~nm}$ 에서의 흡광도가 $1.000 \pm 0.02$ 가 되도 록 메탄올로 희석하였다. 그 다음 메탄올로 희석시켜 준비 한 시료용액 $100 \mu \mathrm{L}$ 에 희석 $\mathrm{DPPH}$ 용액 $900 \mu \mathrm{L}$ 를 첨가하여 혼합하고 30 분간 암소에서 반응시킨 후 $517 \mathrm{~nm}$ 에서의 흡광 도를 측정하였다. 대조구는 시료용액 대신 동량의 메탄올 을 사용하였으며 $\mathrm{DPPH}$ 라디칼 소거능은 시료 농도별 흡광 도의 감소 퍼센트 [Inhibition $\left.(\%)=\left(1-\mathrm{OD}_{\text {sample }} / \mathrm{OD}_{\text {control }}\right) \times 100\right]$ 를 계산한 후 표준물질로 trolox를 이용한 표준곡선을 작성 하여 trolox 당량 $(\mathrm{mmol} / \mathrm{kg})$ 으로 나타내었다.

\section{ABTS 라디칼 소거능}

$\mathrm{Kim}$ 의 방법(29)에 따라 시료의 $\mathrm{ABTS}$ 라디칼 소거능을 분석하였다. 먼저 $7 \mathrm{mM}$ 의 $\mathrm{ABTS}$ 용액에 potassium persulfate를 $2.45 \mathrm{mM}$ 농도로 녹인 후 상온의 암소에서 12 16시간 동안 방치하여 ABTS 라디칼을 생성시킨 후 734 $\mathrm{nm}$ 에서의 흡광도가 $0.700 \pm 0.02$ 범위가 되도록 메탄올로 희석시켜 ABTS 라디칼 용액을 제조하였다. 그 다음 메탄올 로 희석시켜 준비한 시료용액 $50 \mu \mathrm{L}$ 에 ABTS 라디칼 용액 $950 \mu \mathrm{L}$ 를 첨가하여 정확히 6분간 반응시킨 후 $734 \mathrm{~nm}$ 에서 의 흡광도를 측정하였다. 대조구는 시료용액 대신 동량의 메탄올을 사용하였으며 $\mathrm{ABTS}$ 라디칼 소거능은 시료 농도 별 흡광도의 감소 퍼센트[Inhibition $(\%)=\left(1-\mathrm{OD}_{\text {sample }} / \mathrm{OD}_{\text {control }}\right)$ $\times 100]$ 를 계산한 후 표준물질로 trolox를 이용해 표준곡선을 작성하여 trolox 당량으로 나타내었다.

\section{$\mathrm{Fe}(\mathrm{III})$ 이온 환원능}

$\mathrm{Fe}$ (III) 이온을 $\mathrm{Fe}(\mathrm{II})$ 이온으로 환원시키는 능력(ferric reducing antioxidant power, FRAP)을 측정하는 FRAP법은 $\mathrm{Kim}$ 의 방법(29)에 준하여 실시하였다. 이를 위해 먼저 300 $\mathrm{mM}$ 아세트산염 완충액(pH 3.6), $10 \mathrm{mM} \mathrm{TPTZ} \mathrm{용액(10} \mathrm{mM}$ 염산용액에 녹임) 및 $20 \mathrm{mM} \mathrm{FeCl}_{3}$ 용액을 $10: 1: 1(\mathrm{v} / \mathrm{v})$ 비율 로 섞어 FRAP 용액을 조제하였다. 그 다음 메탄올로 희석 시켜 준비한 시료용액 $50 \mu \mathrm{L}$ 에 $37^{\circ} \mathrm{C}$ 로 미리 가온한 FRAP 용액 $950 \mu \mathrm{L}$ 를 혼합하고 30 분 간 암소에서 반응시킨 후 $593 \mathrm{~nm}$ 에서의 흡광도 측정하였으며 대조구는 시료용액 대 신 동량의 메탄올을 사용하였다. 항산화능은 $593 \mathrm{~nm}$ 에서 흡광도를 0.1 증가시키는 농도 $\left(\mathrm{EC}_{\triangle 0.1}\right)$ 로 정의하였고 trolox 의 $\mathrm{EC}_{\triangle 0.1}$ 과 비교하여 trolox 당량으로 나타내었다.

\section{퍼록시 라디칼 소거능}

퍼록시 라디칼(ROO·) 소거능은 Huang 등(30)의 oxygen radical absorbance capacity(ORAC)법을 일부 변형시켜 분 석하였다. 먼저 분말시료에 $75 \%$ 에탄올을 $1: 50(\mathrm{w} / \mathrm{v})$ 비율 로 첨가하여 2 시간동안 vortexing하고 $4^{\circ} \mathrm{C}, 10,000 \times \mathrm{g}$ 조건에
서 10 분간 원심분리하여 상등액을 얻었다. 그 다음 이 상등 액을 진공농축(CentriVap Concentrator, Labconco Co., Kansas, MI, USA)시켜 얻은 농축물에 동량의 $75 \mathrm{mM}$ phosphate buffer(pH 7.4)를 첨가해 재용해시켜서 시료용액 으로 하였으며, 나머지 시약들도 $75 \mathrm{mM}$ phosphate buffer에 녹여 사용하였다. 퍼록시 라디칼 소거능 분석을 위해 시료 용액 $25 \mu \mathrm{L}$ 와 $80 \mathrm{nM}$ sodium fluorescein 용액 $125 \mu \mathrm{L}$ 를 96-well microplate에 넣고 3 분 동안 shaking 한 후 $37^{\circ} \mathrm{C}$ 에서 30 분간 반응시켰다. 여기에 사용직전에 제조한 $75 \mathrm{mM}$ $\mathrm{AAPH}$ 용액 $50 \mu \mathrm{L}$ 를 첨가한 다음 $37^{\circ} \mathrm{C}$ 에서 40 분간 형광 (excitation $485 \mathrm{~nm}$, emission $528 \mathrm{~nm}$ )의 변화를 microplate reader(Biotek $®$ Instruments Inc., Colmar Cedex, France)를 사용해 1 분 마다 측정하였다. 그 결과 얻어지는 형광감소곡 선의 아래 면적(area under the curve, AUC)은 AUC= $0.5+f_{1} / f_{0}+\ldots f_{1} f_{0}+\ldots+f_{39} / f_{0}+0.5\left(f_{40} / f_{0}\right)$ 식을 이용해 계산하였으 며, 여기서 $f_{0}$ 는 0 분, $f_{i}$ 는 $\mathrm{i}$ 분에서의 형 광 값을 나타낸다. 대조구는 시료용액 대신 동량의 $75 \mathrm{mM}$ phosphate buffer를 사용하였다. 시료의 퍼록시 라디칼 소거능은 시료 첨가구 의 $\mathrm{AUC}$ 값에서 대조구의 $\mathrm{AUC}$ 값를 제한 순면적(net $\mathrm{AUC}=\mathrm{AUC}_{\text {sample }}-\mathrm{AUC}_{\text {control }}$ 을 구한 후 trolox로부터 얻어진 표준곡선을 이용하여 trolox 당량으로 나타내었다.

\section{멜라토닌 함량}

총 페놀 함량 분석 시 얻은 메탄올 추출물 $0.6 \mathrm{~mL}$ 를 진공 농축시킨 다음 증류수 $0.6 \mathrm{~mL}$ 을 넣고 30초간 votexing하여 재용해시켜 시료용액으로 사용하였으며, 멜라토닌 함량분 석은 ELISA kit의 방법(19)에 준하여 실시하였다. 즉, 재용 해시킨 시료용액 $0.5 \mathrm{~mL}$ 와 동량의 증류수를 미리 활성화시 킨 Sep-Pak $\mathrm{C}_{18}$ 칼럼에 넣고 $120 \times \mathrm{g}$ 에서 5 분간 원심분리하여 멜라토닌을 칼럼에 부착시켰다. 이후 $10 \%$ 메탄올 $1 \mathrm{~mL}$ 를 추가하여 $500 \times \mathrm{g}$ 에서 1 분간 원심분리하여 방해 물질들을 제거시킨 다음(2회), $1 \mathrm{~mL}$ 메탄올로 멜라토닌을 추출하였 다. 이 추출물을 다시 진공농축시킨 후에 증류수 $0.15 \mathrm{~mL}$ 를 첨가하여 용해시킨 다음, $50 \mu \mathrm{L}$ 를 goat-anti-rabbit antibody 로 코팅된 microtiter plate의 well에 첨가하였다. 여기에 멜 라토닌-바이오틴 용액 및 항혈청 용액을 순서대로 $50 \mu \mathrm{L}$ 씩 첨가한 후 $4^{\circ} \mathrm{C}$ 에서 15 시간 반응시킨 다음 $0.25 \mathrm{~mL}$ 의 wash buffer로 3회 세척하였다. 그 다음 $0.15 \mathrm{~mL}$ 의 anti-biotinalkaline phosphatase 용액을 첨가하고 상온에서 2 시간 반응 시킨 후 $0.25 \mathrm{~mL}$ wash buffer로 3회 세척하였다. 마지막으로 $0.2 \mathrm{~mL}$ 의 p-nitrophenyl phosphate 용액을 첨가하여 $500 \mathrm{rpm}$ 의 orbital shaker에서 20분간 반응시킨 후 $1 \mathrm{~N} \mathrm{NaOH}$ 용액 $50 \mu \mathrm{L}$ 를 첨가하여 반응을 정지시켰다. 이후 microplate reader를 이용해 $605 \mathrm{~nm}$ 를 기준파장으로 하여 $405 \mathrm{~nm}$ 에서 의 흡광도를 측정한 후 표준 멜라토닌을 이용한 표준곡선으 로부터 시료의 멜라토닌 함량을 산출하였다. 


\section{통계 처리}

일반성분 및 항산화능 분석은 3 회, 멜라토닌 분석은 4 회 실시하였으며 그 결과는 평균 \pm 표준편차로 나타내었다. 실 험 결과는 IBM SPSS Statistics(18, IBM Corp., Armonk, NY, USA)를 이용하여 one way ANOVA법으로 분산분석을 하 였으며, $\mathrm{p}<0.05$ 수준에서의 조사항목 간 유의성을 검정하기 위해 Duncan의 다중검정법을 수행하였다.

\section{결과 및 고찰}

일반성분의 변화

10 일의 발아동안 싹의 길이가 거의 직선적으로 증가하여 10 일에 평균 $8.28 \mathrm{~cm}$ 에 도달하였고 8 일의 발아율은 $81.3 \%$ 에 달해 종자의 정상적인 발아와 싹의 생육이 이루어졌음을 알 수 있었다(Table 1). 일반성분의 경우(Table 1), 종자에서 $3.23 \%$ 이었던 수분함량은 발아에 따라 점차 증가하여 10 일 에 $17.50 \%$ 에 도달하였다. 발아 시 수분함량의 증가는 들깨 종자(29)의 발아에서와 유사하였는데 수화되는 세포의 수 가 증가에 기인한 것으로 알려져 있다(31). 조회분함량은 발아기간 동안 4.03 4.91\%로 큰 변화가 없었는데 식물의 회분이 주로 생육토양에 의해 영향을 받는 점을 고려하면, 발아에 단순히 동일한 물만을 사용하였기에 때문으로 판단 된다(15). 종자의 조지방함량 $(38.18 \%)$ 은 발아 2 일에 $43.85 \%$ 로 약간 증가한 이후 8 일에 $20.88 \%$ 까지 감소하였고 이후 유의적 차이는 없었다. 이러한 경향은 Thompson과 Serraino(15)의 결과와 일치하였으며 Zhang 등(32)도 발아 2 일부터 지방의 감소를 보고한 바 있다. 발아에 따른 지방감 소는 일반적인 현상으로, 종자의 중성지방이 가수분해되며 생성된 유리지방산은 $\beta$-산화를 통해 acetate로 분해된 후 glyoxylate cycle을 거쳐 당으로 전환되거나 에너지 생산에 사용되기 때문으로 알려져 있다(33). 종자의 탄수화물함량 $(32.71 \%)$ 은 발아 2 일에 $22.95 \%$ 로 감소한 이후 점차 증가하 여 8 일에 $35.84 \%$ 가 되어 조지방함량 변화와 반대 양상을 보였는데, 이는 발아에 따른 지방 분해와 싹에 필요한 탄수 화물 합성이 밀접히 연관되고 세포벽 합성을 위한 다당류의
합성도 증가하기 때문으로 생각된다(34). 한편, 10 일에 $28.55 \%$ 로 감소한 것은 저장지방의 감소 후에도 싹의 성장 에 필요한 에너지는 필요하므로 발아 초기에 합성되었던 탄수화물이 분해되어 에너지원으로 사용되었기 때문으로 추정된다 $(35,36)$. 종자의 단백질함량 $(21.43 \%)$ 은 6 일까지 는 유의적 변화가 없었으나 8 일부터 증가하여 10 일에 $26.72 \%$ 에 도달하였는데 Thompson과 Serraino(15)도 유사 한 경향을 보고한 바 있다. 발아 시 단백질함량 증가는 새로 운 식물발생과 관련되어 새로운 효소가 합성되기 때문(35) 이거나 발아동안 호흡에 의해 탄수화물이 손실되어 건조중 량이 감소했기 때문(37)으로 추정된다. 환원당함량은 발아 동안 증가하여 6 일에 최고값인 $10.47 \%$ 에 달하였는데 발아 동안 탄수화물의 가수분해(34,36)와 glyoxylate 회로를 통한 저장지방으로부터의 합성(33)에 기인한 것으로 생각된다. 조섬유함량은 2 일 발아싹(9.91\%)에서 종자(12.82\%)보다 낮았으나 4일에 $16.44 \%$ 로 크게 증가하여 6일에 유사한 값 을 보였고 이후 큰 감소는 없었다. 이는 발아초기에 탄수화 물이 에너지원으로 주로 사용되어 섬유소 합성이 적지만 이 후에는 싹의 성장에 따라 조직 형성에 필요한 세포벽 성분의 합성이 증가하였기 때문으로 판단되며(29), Zielińnki 등(12)도 발아에 따라 십자화과 싹에서 식이섬유 증가를 보고한 바 있다.

\section{총 페놀함량의 변화}

페놀화합물은 페놀성 수산기를 가진 방향족 구조로 인해 전자나 수소원자공여를 통한 항산화능이 크며(38) 식물에 서 산화적 스트레스에 대응하는 2차 대사산물 중 하나로 알려져 있다(39). 특히 발아동안 활발한 산화적 대사에 의해 증가된 활성산소가 세포에 산화적 손상을 유발할 수 있는데 $(40,41)$ 페놀화합물은 활성산소 소거를 통해 조직을 보호하 고 성공적인 발아에 도움을 준다고 알려져 있다 $(40,42)$. 종 자의 총 페놀함량 $(7.4 \mathrm{~g} / \mathrm{kg})$ 은 발아 2 일부터 유의적으로 증 가하여 모든 싹에서 종자보다 높았고 8 일에는 최고값인 $16.8 \mathrm{~g} / \mathrm{kg}$ 에 도달하였다(Fig. 1). 발아 시 페놀함량의 증가는 신규 페놀화합물의 생성과 더불어 종자에 존재하고 있던 에스터 또는 글라이코사이드 형태의 페놀화합물이 가수분

Table 1. Changes in length and approximate composition of rapeseed during germination

\begin{tabular}{|c|c|c|c|c|c|c|c|c|}
\hline \multirow{2}{*}{$\begin{array}{l}\text { Gemination period } \\
\text { (day) }\end{array}$} & \multirow{2}{*}{$\begin{array}{l}\text { Length } \\
(\mathrm{cm})\end{array}$} & \multicolumn{7}{|c|}{ Approximate composition (\%) } \\
\hline & & Moisture & Crude ash & Crude fat & Crude protein & Carbohydrate & Reducing sugar & Crude fiber \\
\hline 0 & $0.20 \pm 0.05^{\mathrm{al})}$ & $3.23 \pm 0.16^{\mathrm{a}}$ & $4.44 \pm 0.28^{\mathrm{ab}}$ & $38.18 \pm 0.62^{\mathrm{a}}$ & $21.43 \pm 0.27^{\mathrm{a}}$ & 32.71 & $4.04 \pm 0.38^{\mathrm{a}}$ & $12.82 \pm 0.36^{\mathrm{a}}$ \\
\hline 2 & $1.88 \pm 0.92^{b}$ & $7.88 \pm 0.25^{b}$ & $4.03 \pm 0.30^{\mathrm{a}}$ & $43.85 \pm 1.34^{b}$ & $21.28 \pm 0.47^{\mathrm{a}}$ & 22.95 & $3.62 \pm 1.03^{\mathrm{a}}$ & $9.91 \pm 1.11^{b}$ \\
\hline 4 & $3.44 \pm 1.04^{\mathrm{c}}$ & $10.36 \pm 0.60^{c}$ & $4.31 \pm 0.19^{\mathrm{a}}$ & $39.23 \pm 0.72^{\mathrm{a}}$ & $21.28 \pm 0.51^{\mathrm{a}}$ & 24.82 & $9.39 \pm 0.73^{b c}$ & $16.44 \pm 1.02^{\mathrm{c}}$ \\
\hline 6 & $6.37 \pm 1.09^{\mathrm{d}}$ & $11.93 \pm 0.63^{\mathrm{d}}$ & $4.89 \pm 0.29^{b}$ & $26.26 \pm 3.74^{c}$ & $21.30 \pm 0.13^{\mathrm{a}}$ & 35.62 & $10.47 \pm 0.51^{b}$ & $15.12 \pm 0.23^{\mathrm{cd}}$ \\
\hline 8 & $7.56 \pm 1.64^{\mathrm{e}}$ & $16.08 \pm 0.45^{\mathrm{e}}$ & $4.91 \pm 0.84^{\mathrm{b}}$ & $20.88 \pm 0.83^{\mathrm{d}}$ & $22.28 \pm 0.46^{b}$ & 35.84 & $8.42 \pm 0.00^{\mathrm{c}}$ & $14.60 \pm 1.05^{\mathrm{d}}$ \\
\hline 10 & $8.28 \pm 1.70^{f}$ & $17.50 \pm 1.48^{\mathrm{f}}$ & $4.57 \pm 0.17^{\mathrm{ab}}$ & $22.65 \pm 1.91^{\mathrm{d}}$ & $26.72 \pm 0.30^{c}$ & 28.55 & $9.38 \pm 0.84^{\mathrm{bc}}$ & $14.52 \pm 0.11^{\mathrm{d}}$ \\
\hline
\end{tabular}

${ }^{1)}$ Means $\pm \mathrm{SD}$ with different letters in the column are significantly different at $\mathrm{p}<0.05$ ( $\mathrm{n}=30$ in length, $\mathrm{n}=3$ in approximate composition) 


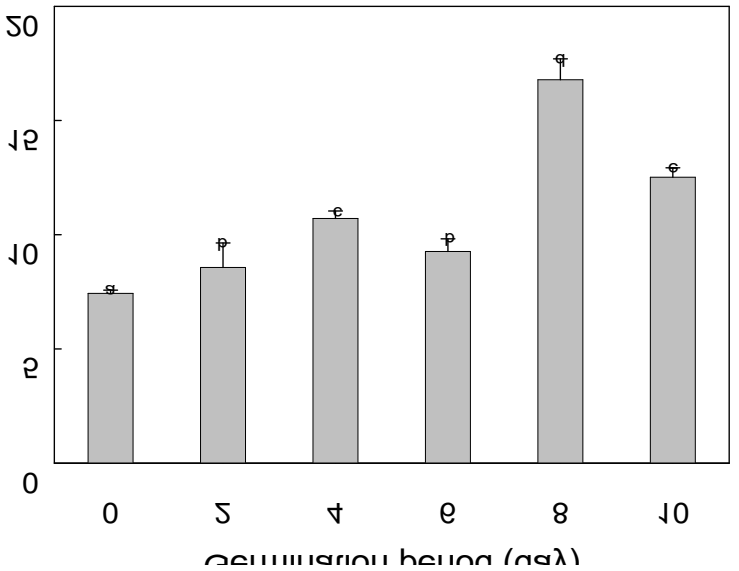

Fig. 1. Change in total phenol content of rapeseed during germination.

Means with different letters above bars are significantly different at $\mathrm{p}<0.05 \quad(\mathrm{n}=3)$.

해되거나 탄닌같은 고분자 형태의 폴리페놀이 가수분해되 면서 유리 페놀화합물이 증가한 결과로 여겨진다 $(43,44)$. 실제로 유채종자에는 sinapic acid의 choline ester 유도체인 sinapine이 총 페놀화합물의 86 91\%, 당 유도체인 sinapoyl glucose가 10 12\%를 차지하는 반면 유리 페놀산인 sinapic acid은 1.0 1.6\% 수준이다(6,7). 10일에서의 총 페놀함량이 8 일에 비해 감소 $(12.5 \mathrm{~g} / \mathrm{kg})$ 한 것은 발아후기에 polyphenol oxidase같은 효소의 활성화로 페놀화합물이 산화되기 때문 으로 추정된다(45). 한편, Folin-Ciocalteu법에 의한 총 페놀 함량 분석은 항산화능에 기초한 것으로 그 결과가 시료의 항산화능 지표로도 사용되지만 Folin-Ciocalteu 시약이 매 우 강한 산화제이므로, 일반적인 항산화물질로 인식되지 않는 당류나 아미노산, 금속이온 등도 측정되는 문제점이 있다(46). 이에 기능성으로서의 항산화능을 평가하기 위해 서는 다른 분석법을 통해 보완할 필요가 있다.

\section{항산화능의 변화}

항산화능 평가에 있어 총 페놀함량 분석의 문제점, 그리 고 혼합 시료에서의 항산화능이 분석법에 따라 차이가 있음 을 고려하여 Prior 등(47)은 항산화능 분석 시 한 가지 방법 이 아니라 다른 기작을 가진 여러 분석법들을 적용하여 평가할 필요가 있다고 하였다. 이에 항산화능 분석에 널리 쓰이는 DPPH법, ABTS법, FRAP법 및 ORAC법을 이용해 발아동안 항산화능 변화를 분석하였으며 그 결과는 Fig. 2 와 같았다.

$\mathrm{DPPH}$ 법은 수 시간 안정성이 높은 $\mathrm{DPPH}$ 라디칼에 전자 혹은 수소원자를 전달하여 환원시키는 항산화제의 능력, 즉 $\mathrm{DPPH}$ 라디칼 소거능을 평가하는 방법으로 메탄올 용매 조건에서는 주로 항산화제의 전자전달능을 평가하는 것으 로 알려져 있다(46). 토코페롤의 수용성 유도체인 trolox 당량기준으로 표현한 $\mathrm{DPPH}$ 라디칼 소거능의 경우, 종자 $(17.2 \mathrm{mmol} / \mathrm{kg})$ 의 발아 2 일 부터 유의적으로 증가하여 6 일

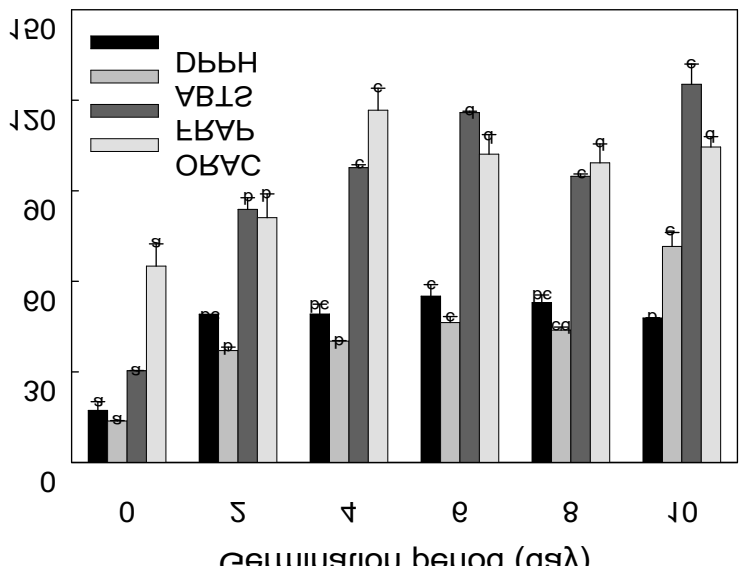

Fig. 2. Changes in antioxidant activity of rapeseed during germination.

Means with different letters above bars within each assay are significantly different at $\mathrm{p}<0.05(\mathrm{n}=3)$.

에 최고값인 $55.9 \mathrm{mmol} / \mathrm{kg}$ 에 도달하였고 이후 다소 감소하 여 10 일에 $47.8 \mathrm{mmol} / \mathrm{kg}$ 이 되었다. ABTS 라디칼 소거능도 메탄올 용매 조건에서는 주로 전자전달능을 평가하는 방법 (46)으로 종자 $(13.7 \mathrm{mmol} / \mathrm{kg})$ 의 발아 2일부터 크게 증가하 여 6 일에 $46.3 \mathrm{mmol} / \mathrm{kg}$ 에 도달한 이후 다소 감소하였으나 유의적인 차이는 없었으며 10 일에 최고값인 $71.6 \mathrm{mmol} / \mathrm{kg}$ 에 도달하였다. 한편, 항산화제로부터 수소원자전달의 가 능성을 완전히 배제하고 순수하게 전자전달능만을 평가하 기 위하여 $\mathrm{Fe}(\mathrm{III})$ 이온 환원능을 평가하는 FRAP법(46,47)을 실시한 결과, 앞의 두 방법에서 얻어진 결과와 마찬가지로 발아 2일부터 항산화능이 크게 증가하여 6일에 115.9 $\mathrm{mmol} / \mathrm{kg}$ 에 도달하였고 8 일에 다소 감소한 후 10 일에서는 $\mathrm{ABTS}$ 라디칼 소거능과 마찬가지로 최고값 $(125.3 \mathrm{mmol} / \mathrm{kg})$ 에 도달하였다. 이상 3 가지 방법의 결과로 볼 때, DPPH 라디칼 소거능은 6일, $\mathrm{ABTS}$ 라디칼 소거능 및 $\mathrm{Fe}(\mathrm{III})$ 이온 환원능은 10 일 싹에서 높았다. 즉, 발아 6 일까지 항산화능 이 증가하다가 8 일에 다소 감소하는 경향은 3 가지 방법 모두에서 유사하였고 10 일 싹의 경우만 차이를 보였다. 이 러한 차이는 $\mathrm{DPPH}$ 라디칼의 환원전위가 $\mathrm{ABTS}$ 라디칼과 $\mathrm{Fe}(\mathrm{III})$ 이온의 환원전위보다 낮아 전자전달능이 약한 물질 은 $\mathrm{DPPH}$ 법에 의해 분석되지 않았기 때문으로 추정되며 (48), 10 일 싹의 경우 항산화물질의 양은 증가하였지만 전자 전달능이 강한 항산화물질은 오히려 감소하였을 것으로 생각할 수 있다. 한편, 총 페놀함량도 항산화능과 관련이 되지만 앞서 언급한 바와 같이 시약의 강한 산화특성으로 인해 일반적인 항산화물질로 인식되지 않는 성분들도 분석 되기에(46) Folin-Ciocalteu법 보다는 이들 3가지 방법에 의 한 결과가 기능성으로서의 항산화능 평가에 더 적합하다고 판단된다. $\mathrm{DPPH}, \mathrm{ABTS}, \mathrm{FRAP}$ 법의 경우, 사용한 라디칼이 나 시약들은 생체나 식품에 존재하는 것이 아니어서 생체나 식품에서의 항산화능과는 차이가 있을 수 있다. 이에 생리 
적 조건과 유사한 $\mathrm{pH} 7.4,37^{\circ} \mathrm{C}$ 수용액 조건에서 지질산화와 관련된 퍼록시(ROO-) 라디칼에 대한 소거능을 측정하는 $\mathrm{ORAC}$ 법(49)을 이용해 항산화능을 추가로 평가하였다. 그 결과(Fig. 2), 종자에서 $65.1 \mathrm{mmol} / \mathrm{kg}$ 이었던 항산화능이 발 아에 따라 증가하여 4일에 최고값인 $116.7 \mathrm{mmol} / \mathrm{kg}$ 에 도달 하였으며 이후 다소 감소하였다. 이러한 차이 중의 하나는 앞의 3 가지 방법들이 항산화물질의 전자전달능을 평가하 는 것과는 달리 $\mathrm{ORAC}$ 법에서는 수소원자전달능을 평가하 는 것이기 때문으로 여겨지며 Apak 등(49)도 ORAC법의 결과가 전자전달능 평가법의 결과와 차이가 있을 수 있다고 하였다. 한편, 전자전달능 분석법에서 우수하였던 6 일 싹도 4 일 싹 대비 $87 \%$ 수준 $(102.1 \mathrm{mmol} / \mathrm{kg})$ 의 높은 퍼록시 라디 칼 소거능을 나타내었다.

유채종자의 발아 시 항산화능 증가에 영향을 주는 성분 들로는 페놀화합물 $(43,44)$ 외에도 토코페롤이나 비타민 C, 글루타치온 등(16-18)이 알려져 있는데 특히 비타민 C 함량 의 증가 영향이 큰 것으로 알려져 있다(50).

\section{멜라토닌함량의 변화}

한편, 기존에 알려진 페놀화합물이나 항산화성분 외에 유채싹의 새로운 기능성 성분으로 멜라토닌함량을 분석하 였다. 멜라토닌은 1995년 식물체에서 처음 발견된 이래 많 은 식물체에서 수 $\mathrm{ng} / \mathrm{kg}$ 에서 수십 $\mathrm{mg} / \mathrm{kg}$ 수준으로 존재하는 것으로 확인되었으며 식물에서의 성장조절자, 형태형성인 자, 신호분자로 작용하며 스트레스 완화, 병충해 방어, 노화 지연과도 관련된다고 추정되고 있다(24). 그리고 식물기관 중에서 특히 종자에 함량이 높다고 알려져 있는데 이는 저장지방의 산화방지, 종자의 생존성 및 발아력 증진과 관 련되기 때문으로 여겨진다(24). 또한 맥주, 와인, 올리브유 등과 같은 식물 유래의 식품(25)에서도 멜라토닌이 발견되 었으며 이들의 섭취 시 멜라토닌은 체내에 흡수되어 혈청의 항산화 활성을 증가시킬 수 있음이 보고된 바 있어(26) 멜라 토닌 함유 식품은 새로운 기능성 식품으로 평가될 수 있다.

최근 $\operatorname{Kim}(19)$ 은 4 일 발아 유채싹에서 $2.41 \mathrm{\mu g} / \mathrm{kg}$ 의 멜라 토닌이 존재함을 확인한 바 있으나 발아기간별 그 함량변화 는 확인하지 않았다. 이에 유채종자의 발아기간별 싹에 대 한 분석을 실시한 결과(Fig. 3), 종자에서 $0.85 \mu \mathrm{g} / \mathrm{kg}$ 이었던 멜라토닌함량은 발아에 따라 증가해 6일에 최고값(14.93 $\mu \mathrm{g} / \mathrm{kg}$ )에 도달하였다. 그리고 멜라토닌의 강한 항산화능 $(21,22)$ 을 고려할 때 발아초기 항산화능의 증가에도 기여할 것으로 판단된다. 그러나 10 일에는 $8.35 \mu \mathrm{g} / \mathrm{kg}$ 으로 감소하 여 $\mathrm{ABTS}, \mathrm{FRAP}, \mathrm{ORAC}$ 법의 결과 보다는 $\mathrm{DPPH}$ 법의 결과 와 유사하였다.

이상의 결과로부터 발아시킨 싹의 섭취는 항산화능과 멜라토닌 함량 측면에서 종자보다 유용함을 알 수 있었다. 분석방법에 따라 차이는 다소 있지만 4 일 이상 발아시킨 싹에서 전반적으로 항산화능이 높아 이 싹들은 항산화 식품

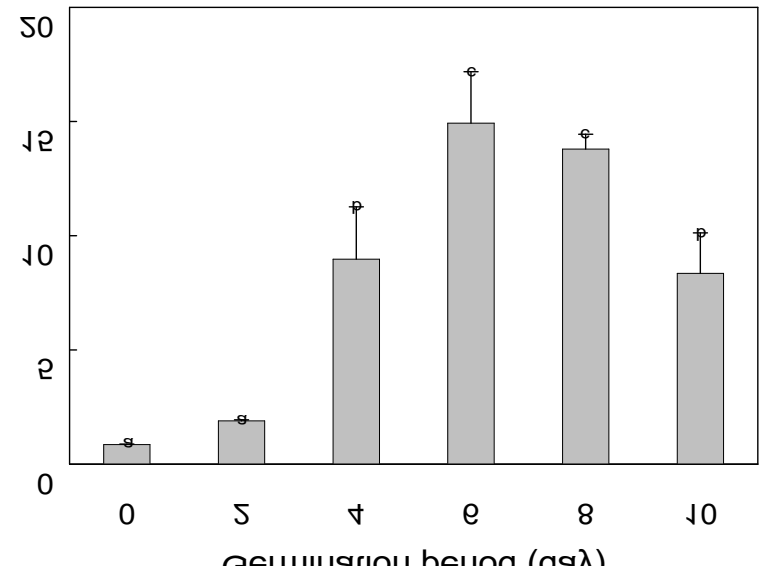

Fig. 3. Change in melatonin content of rapeseed during germination.

Means with different letters above bars are significantly different at $p<0.05 \quad(n=4)$.

으로서의 가치가 있다고 판단되며 실지 시판 십자화과 싹도 대개 4 일간 발아시킨 것이다(28). 그러나 항산화능 평가에 추가적으로 멜라토닌, 환원당 및 조섬유와 같은 유용 성분 을 함께 고려했을 때에는 6일 싹이 가장 적합한 것으로 판단된다. 한편, 10 일과 같이 장기간 발아는 미생물 오염 증가나 식감 감소의 문제가 있다고 여겨진다 $(27,28)$.

\section{요 약}

본 연구에서는 유용한 기능성을 지닌 최적의 유채싹 선 발을 위해 종자를 10 일 동안 발아시키면서 일반성분, 항산 화능 및 멜라토닌함량 변화를 분석하였다. 종자의 수분함 량(3.23\%)은 발아동안 점차 증가하여 10 일에 $17.50 \%$ 에 도 달하였으나 조회분함량은 4.03 4.91\%로 큰 변화가 없었다. 조지방함량은 종자의 $38.18 \%$ 로부터 감소하여 10 일에 $22.65 \%$ 가 되었으며 조단백질함량은 $21.43 \%$ 에서 10 일에 $26.72 \%$ 에 이르렀다. 탄수화물함량은 8 일까지 $35.84 \%$ 로 증 가한 후 10 일에 $28.55 \%$ 로 감소하였다. 환원당함량은 6 일에 최고값(10.47\%)에 도달하였고 조섬유함량도 $15.12 \%$ 로 높 은 값을 나타내었다. 총 페놀함량(gallic acid equivalent)은 발아에 따라 증가하다가 8 일에 최고값인 $16.8 \mathrm{~g} / \mathrm{kg}$ 에 도달 하였다. 항산화능(trolox equivalent, $\mathrm{mmol} / \mathrm{kg}$ )은 발아에 따 라 증가하여 4 10일에 좀 더 높은 값을 나타내었는데 분석 법에 따라 최고값을 보이는 시기는 다소 차이가 있었다. 즉, DPPH 라디칼 소거능은 6일(55.9), ABTS 라디칼 소거능 (46.3)과 $\mathrm{Fe}(\mathrm{III})$ 이온 환원능(125.3)은 10 일, 퍼록시 라디칼 소거능은 4일(116.7)에서 최고값을 보였다. 종자에서 0.85 $\mu \mathrm{g} / \mathrm{kg}$ 이던 멜라토닌함량도 발아에 따라 증가하여 6일에 최 고값 $(14.93 \mu \mathrm{g} / \mathrm{kg})$ 을 나타내었다. 이상의 결과로부터 항산 화소재로서는 4 10 일까지의 발아싹들을 이용될 수 있다고 
생각된다. 그러나 멜라토닌 함량, 환원당, 조섬유와 같은 추가적인 기능성분을 함께 고려하면 6일 발아싹이 기능성 싹으로서 적합하다고 판단된다.

\section{감사의 글}

이 논문은 2013년도 동덕여자대학교 연구년제도 지원에 의하여 수행된 것으로, 이에 감사드립니다.

\section{References}

1. Lee TS, Lee YH, Kim KS, Lee HK, Jang YS, Choi IH, Kim KS (2014) Effect of sowing time on oil content and fatty acid composition characteristics in rapeseed cultivars. Korean J Plant Res, 27, 202-208

2. McDonald BE (2004) Food uses and nutritional properties. In : Rapeseed and Canola Oil, Gunstone FD (Editor), Blackwell Publishing, Oxford, UK, p 131-153

3. Malgorzata NK, Aleksander S (2010) Changes of phenolic content in rapeseed during preliminary drying. J Oilseed Brassica, 1, 33-38

4. Amar S, Becker HC, Mollers C (2009) Genetic variation in phytosterol content of winter rapeseed (Brassica napus L.) and development of NIRS calibration equations. Plant Breed, 128, 78-83

5. Piao X, Choi SY, Kin YH, Lee YH, Kim KS, Jang YS, So YS, Kim HS (2013) Variety $\times$ location interaction on oil, fatty acids, tocopherols and phytosterols in Korean rapeseed (Brassica napus L.). Plant Breed Biotech, 1, 91-101

6. Naczk M, Amarowicz R, Sulivan A, Shahidi F (1998) Current research developments on polyphenolics of rapeseed/canola: A review. Food Chem, 62, 489-502

7. Khattab R, Eskin M, Aliani M, Thiyam U (2010) Determination of sinapic acid derivatives in canola extracts using high-performance liquid chromatography. J Am Oil Chem Soc, 87, 147-155

8. Bell JM (1984) Nutrients and toxicants in rapeseed meal: A review. J Anim Sci 58, 996-1010

9. Tripathi MK, Mishra AS (2006) Glucosinolates in animal nutrition: a review. Anim Feed Sci Technol, 132, 1-27

10. Lajolo FM, Lanfer Marquez UM, Filisetti-Cozzi TMCC, Ian McGregor D (1981) Chemical composition and toxic compounds in rapeseed (Brassica napus, L.) cultivars grown in Brazil. J Agric Food Chem, 39, 1933-1937
11. Shahidi F (1990) Canola and Rapeseed: Production, Chemistry, Nutrition, and Processing Technology. Van Nostrand Reinhold, NY, USA, p 3-23

12. Zielinski H, Frias J, Piskuła MK, Kozlowska H, Vidal-Valverde $C$ (2005) Vitamin $B_{1}$ and $B_{2}$, dietary fiber and minerals content of cruciferae sprouts. Eur Food Res Technol, 221, 78-83

13. Bellostas N, Kachlicki P, Sorensen H, Sorensen JC (2007) Glucosinolate profiling of seeds and sprouts of $B$. Oleracea varieties used for food. Sci Hortic, 114, 234-242

14. Dawood MG, Sadak MS, Reyad BY, El-Sayed ASM, El-Gayar SH (2013) Changes in chemical composition during germination of some canola varieties changes in oil content and fatty acid composition. Sci Agri, 2, 77-82

15. Thompson LU, Serraino MR (1985) Effect of germination on phytic acid, protein and fat content of rapeseed. J Food Sci, 50, 1200

16. Zhang H, Vasanthan T, Wettasinghe M (2007) Enrichment of tocopherols and phytosterols in canola oil during seed germination. J Agric Food Chem, 55, 355-359

17. Zielinski H, Bucinski A, Kozlowska H (2002) Monitoring of the vitamin $\mathrm{C}$ content in germinating cruciferae seeds by HPLC. Pol J Food Nutr Sci, 52, 142-146

18. Zielinski H, Mudway I, Kozlowska H, Kelly FJ (2002) Impact of germination on glutathione content in cruciferous seeds. Pol J Food Nutr Sci, 52, 68-72

19. Kim SJ, Cho MH (2011) Melatonin and polyphenol contents in some edible sprouts (alfalfa, chicory, rape, red kale and sunflower). J Food Sci Nutr, 16, 184-188

20. Reiter RJ (1991) Melatonin: The chemical expression of darkness. Mol Cell Endocrinol, 79, C153-C158

21. Bonnefont-Rousselot D, Collin F (2010) Melatonin: Action as antioxidant and potential applications in human disease and aging. Toxicol, 278, 55-67

22. Tan D-X, Manchester LC, Terron MP, Flores LJ, Reiter RJ (2007) One molecule, many derivatives: a neverending interaction of melatonin with reactive oxygen and nitrogen species? J Pineal Res, 42, 28-42

23. Rodriguez C, Mayo JC, Sainz RM, Antolin I, Herrera F, Martin V, Reiter RJ (2004) Regulation of antioxidant enzymes: A significant role for melatonin. J Pineal Res, $36,1-9$

24. Hardeland R (2016) Melatonin in plants-Diversity of levels and multiplicity of functions. Front Plant Sci, 7, doi: $10.3389 /$ fpls.2016.00198

25. Iriti M, Vitalini S, Rossoni M, Faoro F (2012) Chap 
29. Occurrence and analysis of melatonin in food plants. In : Handbook of Analysis of Active Compounds in Functional Foods, Mollet LML, Toldra F (Editor), CRC Press, Boca Raton, FL, USA, p 651-662

26. Sae-Teaw M, Johns J, Johns NP, Subongkot S (2013) Serum melatonin levels and antioxidant capacities after consumption of pineapple, orange, or banana by healthy male volunteers. J Pineal Res, 55, 58-64

27. Park H, Cha GH, Shin JK, (2016) Sterilization of rapeseed sprouts by intense pulsed light treatment. Korean J Food Sci Technol, 48, 36-41

28. Frias J, Zielinski H, Piskula MK, Kozlowska H, Vidal-Valverde C (2005) Inositol phosphate content and trypsin inhibitor activity in ready-to-eat cruciferous sprouts. Food Chem, 93, 331-336

29. Kim SJ (2012) Inhibitory effect of perilla sprouts extract on oxidation of perilla oil. J Korean Oil Chem Soc, 29, 330-338

30. Huang D, Ou B, Hampsch-Woodill M, Flanagan JA, Prior RL (2002) High-throughput assay of oxygen radical absorbance capacity (ORAC) using a multichannel liquid handling system coupled with a microplate fluorescence reader in 96-Well format. J Agric Food Chem, 50, 4437-4444

31. Nonogaki H, Bassel GW, Bewley JW (2010) Germinationstill a mystery. Plant Sci, 179, 574-581

32. Zhang H, Vasanthan T, Wettasinghe M (2004) Dry matter, lipids, and proteins of canola seeds as affected by germination and seedling growth under illuminated and dark environments. J Agric Food Chem, 52, 8001-8005

33. Borek S, Ratajczak W, Ratajczak L (2015) Regulation of storage lipid metabolism in developing and germinating lupin (Lupinus spp.) seeds. Acta Physiol Plant, 37, doi:10.1007/s11738-015-1871-2

34. Jood S, Chauhan BM, Kapoor AC (1988) Contents and digestibility of carbohydrates of chickpea and black gram as affected by domestic processing and cooking. Food Chem, 30, 113-127

35. Barthet VJ, Daun JK (2005) Effect of sprouting on the quality and composition of canola seed and oil. JAOCS, $82,511-517$

36. Lasekan OO (1996) Effect of germination on a-amylase activities and rheological properties of sorghum (Sorghum bicolar) and acha (Digitaria exilis) grains. J Food Sci Technol, 33, 329-331

37. Uppal V, Bains K (2012) Effect of germination periods and hydrothermal treatments on in vitro protein and starch digestibility of germinated legumes. J Food Sci Technol, 49, 184-191

38. Xie J, Schaich KM (2014) Re-evaluation of the 2,2-diphenyl-1-picrylhydrazyl free radical (DPPH) assay for antioxidant activity. J Agric Food Chem, 62, $4251-4260$

39. Randhir R, Lin YT, Shetty K (2004) Stimulation of phenolics, antioxidant and antimicrobial activities in dark germinated mung bean sprouts in response to peptide and phytochemical elicitors. Process Biochem, 39, 637-647

40. Perl-Treves R, Perl A (2002) Oxidative stress: an introduction. In : Oxidative Stress in Plants. Inze D, van Montagu M (Editor), Taylor \& Francis Inc, London, UK. p 1-32

41. Schopfer P, Plachy C, Frahry G (2001) Release of reactive oxygen intermediates (superoxide radicals, hydrogen peroxide, and hydroxyl radicals) and peroxidase in germinating radish seeds controlled by light, gibberellin, and abscisic acid. Plant Physiol, 125, 1591-1602

42. Wojtyla L, Garnczarska M, Zalewski T, Bednarsk W, Ratajczak L, Jurga S (2006) A comparative study of water distribution, free radical production and activation of antioxidative metabolism in germinating pea seeds. J Plant Physiol, 163, 1207-1220

43. Siger A, Czubinski J, Dwiecki K, Kachlicki P, Nogala Kalucka M (2013) Identification and antioxidant activity of sinapic acid derivatives in Brassica napus L. seed meal extracts. Eur J Lipid Sci Technol, 115, 1130-1138

44. Strack D, Nurmann G, Sachs G (1980) Sinapine esterase. II. Specificity and change of sinapine esterase activity during germination of Raphanus sativus. J Biosci, 35, 11-12

45. Vadivel V, Biesalski HK (2012) Effect of certain indigenous processing methods on the bioactive compounds often different wild type legume grains. J Food Sci Technol, 49, 673-684

46. Apak R, Qzyurek M, Guqlu K, Qapanoglu E (2016) Antioxidant activity/capacity measurement. 1. Classification, physicochemical principles, mechanisms, and electron transfer (ET)-based assays. J Agric Food Chem, 64, 997-1027

47. Benzie IFF, Strain JJ (1996) The ferric reducing ability of plasma as a measure of "antioxidant power": the FRAP assay. Anal Biochem, 239, 70-76

48. Huang D, Ou B, Prior RL (2005) The chemistry behind 
antioxidant capacity assays. J Agric Food Chem, 53, 1841-1856

49. Apak R, Ozyurek M, Guqlu K, Capanoglu E (2016) Antioxidant activity/capacity measurement. 2. Hydrogen atom transfer (HAT)-based, mixed-mode (electron transfer (ET)/HAT), and lipid peroxidation assays. J Agric Food Chem, 64, 1028-1045

50. Zielinski H, Piskula MK, Michalska A, Kozlowska H (2007) Antioxidant capacity and its components of cruciferous sprouts. Pol J Food Nutr Sci, 57, 315-322 